\title{
Jo mer informasjon, jo bedre
}

\author{
Pårørende til pasienter som har blitt påført en alvorlig hjerneskade, har et sterkt behov \\ for informasjon om behandling, rehabilitering og praktiske spørsmål.
}

$\mathbf{T}$ raumatisk hjerneskade er hjerneskade påført ved ytre traume, og rammer cirka 9500 personer i Norge hvert år. Cirka 10-15 prosent av skadene er så alvorlige at langvarig rehabilitering er nødvendig (1). Vedvarende funksjonsproblemer, psykososiale problemer og redusert livskvalitet er noen av de hyppigste langtidskonsekvensene (2).

Denne artikkelen er basert på et kvalitetssikringsprosjekt utført ved Oslo universitetssykehus HF (OUS) i samarbeid med Høgskolen i Oslo og Akershus (HiOA). Prosjektet hadde som mål å få kunnskap om hva pårørende til pasienter med alvorlig traumatisk hjerneskade (TBI), trenger i møte med avdelingen. Alvorlig TBI får ikke bare konsekvenser for dem som er skadet, men også for familiene deres (3-5). Vi søkte svar på spørsmålet: Hvilke ønsker og behov har pårørende til pasienter med traumatisk hjerneskade? Dette fordi vi ønsket å forbedre oss i møte med denne gruppen.

Det er gjort lite forskning på dette feltet. Vi

\section{Hovedbudskap}

Det er viktig at pårørendes behov for informasjon blir kartlagt og ivaretatt mens deres nære er innlagt på sykehus. De har behov for informasjon, omsorg og å bli møtt med respekt.

\section{Nøkkelord}

Les mer og finn litteraturhenvisninger på våre nettsider. / Traume / Pårørende / Rehabilitering fant en norsk studie som omhandlet pårørende generelt og fant flere likheter med våre funn.

\section{Introduksjon}

Enhet for tidlig rehabilitering (ETR, to senger), Intensiv Avdeling, Oslo universitetssykehus, Ullevål har drevet med tidlig rehabilitering av alvorlig TBI siden 2005 (6). Hovedmålet med tidlig rehabilitering er optimal medisinsk behandling for å redusere omfanget av hjerneskade, forebygge komplikasjoner og fremme oppvåkning via multisensorisk stimulering.

Tilbudet ble fra oktober 2009 styrket med to senger ved intermediær rehabiliteringsstue ved Avdeling for fysikalsk medisin og rehabilitering. Pasientene overflyttes fra ETR når de er tatt av respirator, men er fremdeles ikke klare for overflytting til rehabiliteringssykehus. I denne fasen har de fortsatt behov for 24 timers overvåkning for behandling av komplikasjoner og håndtering av forvirring og desorientering $\mathrm{i}$ oppvåkningsfasen (posttraumatisk amnesi fase, PTA). Behandlingsopplegget er tverrfaglig og basert på samarbeid mellom lege, sykepleier, ergoterapeut, fysioterapeut, hjelpepleier, sosionom og nevropsykolog. Sykepleier er til stede ved avdelingen 24 timer i døgnet.

I løpet av sommeren 2010 ble det gjennomført et lite pilotprosjekt i forbindelse med utarbeidelse av behandlingslinjer. 14 pårørende til pasientene innlagt ved avdelingen besvarte et spørreskjema om hvordan de opplevde oppholdet ved avdelingen. Spørreskjemaet var imidlertidig av kvantitativ karakter, og selv om de fleste krysset av for at de var veldig fornøyde med avdelingens tilbud, fikk vi ikke svar på om informasjonsbehovene var dekket og på hvilke områder de trengte mer bistand.

\section{Basert på intervjuer}

I prosjektet har vi brukt kvalitativ metode, deskriptivt intervju med hva- og hvordan-spørsmål (7). Informantene er nærmeste pårørende til pasienter med alvorlig TBI. Vi har intervjuet 15 pårørende til pasienter som fikk tidlig rehabilitering ved vår avdeling, i perioden fra september 2010 til juli 2011. Under intervjuene oppsto det ofte behov for oppfølgingsspørsmål for å få mer konkrete svar fra informanten. Oppfølgingsspørsmålene var av typen «fikk du tilbud om å være med på tverrfaglig møte?», «ble du møtt da du kom til avdelingen?» og «spurte noen om hvordan du hadde det?». To pasienter var under 18 år. Ellers var de i alderen 24-72 år. Vi intervjuet ti kvinner og fem menn. Disse var ektefeller, foreldre, søsken, samboere og barn. For å få frem så bred informasjon som mulig, og flest mulige synspunkter, inkluderte vi pårørende til fire tidligere pasienter og åtte som var inneliggende.

\section{Helst mye informasjon}

Kort oppsummert har det kommet frem at pårørende har behov for mer strukturert informasjon og trygghet. De er også opptatt av at både de selv som pårørende og pasienten blir møtt med empati, respekt og gode holdninger hos sykepleierne.

I alle intervjuene kom det frem at pårørende hadde behov for informasjon. I analysen av intervjuene ble det tydelig at det pårørende ønsket å vite mer om kunne deles inn i fire underkategorier.

Den største underkategorien er behovet for medisinsk informasjon. I nesten alle intervjuene kom det frem at pårørende ønsker fortløpende informasjon om framgang, tilbakegang og prognoser. Vi har sammenliknet våre funn med et fagutviklingsprosjekt gjennomført ved 
Sykehuset Asker og Bærum HF (8), publisert i Sykepleien i 2003. Prosjektet hadde som mål å kartlegge hvordan pårørende opplever at de blir ivaretatt på sykehus. Vi fant flere fellestrekk mellom våre funn og funnene fra dette prosjektet. Det er interessant å merke seg at også et av deres viktigste funn var at pårørende har behov for fortløpende og gjentatt informasjon.

På avdelingen er det i all hovedsak lege som gir den medisinske informasjonen. Vi har tverrfaglige møter med pårørende innen en uke etter overflyttingen til vår avdeling. Det blir gitt mulighet for informasjonsmøte med legen før dette. Ingen informanter opplevde å bli for mye informert. En ektefelle refererte til det tverrfaglige møtet og sa at det ikke nødvendigvis kom frem så mye nytt, fordi hun hadde fått mye informasjon underveis. Hun påpekte likevel at hun satte pris på det, fordi hun syntes det var bra med repetisjon.

Pårørende opplevde at de fikk informasjon når de ba om det, men det varierte om de måtte spørre mye. To søstre etterlyste mer informasjon om hva som skjedde med deres bror fysisk og psykisk. De mente det kunne vært sagt mer om hva som ble gjort og hvorfor.

\section{Struktur viktig}

En liten andel sa at de ikke hadde deltatt på tverrfaglig møte. En hadde takket nei og en fikk ikke tilbudet. Ektefellen til en pasient fortalte at det første møte manglet struktur og at det var og hvorfor ting blir gjort på den måten de blir.

Det varierte hvordan pårørende opplevde at avdelingen jobbet som tverrfaglig team. Flere sier at de ikke oppfattet at det eksisterte et tverrfaglig team, at det ikke var noen presentasjon av de ulike fagpersonene og det var uklart hva de ulike fagpersonene gjorde. Andre derimot opplevde at det tverrfaglige teamet kommuniserte bra. Mange følte seg inkluderte og forsto hensikten med for eksempel trening. De ble forklart hva som ble gjort og de fikk være med på ulike aktiviteter. Siden rehabiliteringen er en stor del av behandlingen på avdelingen, er pårørende opptatt av å få informasjon om dette. Flere sa at det opplevdes positivt å være med i treningssituasjoner. Man tenker at ved å inkludere pårørende i treningen føler de seg ivaretatt og sett på som en ressursperson i pasientens liv. Det er naturlig at pårørende trenger å føle seg trygge i situasjonen og ha tillit til sykepleieren. Man forutsetter at sykepleieren bidrar til å skape grunnlag for dette ved å etablere kontakt, tillit og respekt.

\section{Trenger praktisk informasjon}

Informasjon om det praktiske blir også framhevet som viktig i intervjuene. Det er viktig for pårørende å få en plan for oppholdet og hvor lenge oppholdet skal vare. Noen pårørende savnet spesifikk informasjon om videre rehabilitering etter sykehusoppholdet. Flere har sagt at de var bekymret for hva som skulle skje den dagen

\section{«Pårørende gjennomgår en krise, og mange har problemer med å lagre informasjon og beskjeder.»»}

lite nyttig informasjon som kom frem. Det neste møte denne pårørende hadde vært med på var derimot bra. Da hadde det vært en ordstyrer, og de opplevde at de fikk relevant informasjon.

Dette viser at pårørende trenger et strukturert møte hvor det blir utvekslet relevant informasjon. Tid er satt av til spørsmål pårørende måtte ha, og det er et møte for å diskutere framgang og plan videre. Ut fra intervjuene ser vi at uten struktur og sammenheng på møtene, kan pårørende oppleve at de er til liten nytte. Vi fant at dette var et område hvor vi hadde forbedringspotensial.

\section{Vil delta i rehabilitering}

Informasjon om rehabiliteringsprosessen blir oppgitt av samtlige som viktig. De har behov for informasjon om hva det tverrfaglige teamet gjør pasienten skulle hjem. I tillegg etterlyste de informasjon om hvilke muligheter som finnes etter endt rehabiliteringsopphold. De hadde behov for visittider å forholde seg til og et telefonnummer de kunne ringe. Dette funnet samsvarer også med fagutviklingsprosjektet fra Sykehuset Asker og Bærum HF (8). I artikkelen skriver de at det var viktig for pårørende så det at de kunne ringe når som helst, og at de ikke ble avvist når de tok kontakt.

\section{Gi kort og presis informasjon}

Flere pårørende påpeker også verdien av at informasjonen de får er individuelt tilpasset. Pårørende opplevde at det varierte hvor godt informasjonen de fikk var tilpasset deres behov. Vi så en sammenheng mellom behovet for informasjon og omfanget av skaden. Jo mer alvorlig skaden var, jo mer informasjon hadde pårørende behov for.

Relasjonen til pasienten kan også ha betydning, for eksempel kan det tenkes at moren til en gutt på 18 år har et annet perspektiv og behov for informasjon enn det sønnen til en mann på 72 år har.

Pårørende gjennomgår en krise, og mange har problemer med å lagre informasjon og beskjeder. Det er derfor viktig at informasjonen er kortfattet og presis. Sykepleieren og resten av det tverrfaglige teamet må også tenke over hvilke begreper de bruker når de snakker med pårørende. Et hverdagslig språk er å foretrekke framfor vanskelige medisinske begreper som pårørende kanskje ikke forstår.

\section{Vil bli sett}

Trygghet var også et sentralt tema for pårørende. De uttrykte at det styrket deres trygghet å vite at pasienten ble godt ivaretatt ved avdelingen. Pårørende syntes også at det var viktig at de selv ble sett når de besøkte avdelingen. De verdsatte å bli møtt og hilst på i gangen, at noen hadde tid til å snakke med dem og å bli møtt med interesse og empati.

Pårørende påpekte også at det var viktig for dem at det var tilstrekkelig med bemanning og at personalet var kjent. Oppmerksomhet, omsorg og faglig dyktighet skaper tillit til sykepleieren og avdelingen. Dette vokser frem gjennom ulike faser (9). Første inntrykket i møte med sykepleier og avdeling danner grunnlaget for hvordan oppholdet vil bli. Dette ble også belyst i fagutviklingsprosjektet gjennomført ved Sykehuset Asker og Bærum (8).

En mor i vår undersøkelse nevner at det er viktig med et godt samarbeid mellom intensivavdelingen og fysikalsk medisinsk avdeling, siden overflyttinger ofte kan skape usikkerhet. Når pasienten og pårørende kommer til vår avdeling flyttes de fra intensivavdelingen, de får nye sykepleiere og et nytt team rundt pasienten som de må forholde seg til. Pårørende ønsker forutsigbarhet. De føler seg trygge når de ser at sykepleieren jobber helhetlig og innehar gode teoretiske kunnskaper om pasienten og om hodeskaden.

\section{Verdighet og respekt}

Sykepleierens holdninger påvirker pårørendes opplevelse på avdelingen. De er opptatt av at sykepleieren behandler pasienten med verdighet, respekt og at det blir vist omsorg for den syke. I møte med pårørende og pasient må sykepleieren 
fremstå som et medmenneske samtidig som sykepleieren også skal være profesjonell. Man viser omsorg for den syke og dens pårørende basert på gjensidighet, fellesskap og solidaritet. Pårørende mener at moral, omsorg, empati og

\section{«Flere sier at de ikke opp- fattet at det eksisterte et tverrfaglig team.»}

gode holdninger er viktige ingredienser $\mathrm{i}$ alle sykepleiesituasjoner. Sykepleieren skal være til stede i sitt arbeid, anerkjenne og vise forståelse for den andre ut ifra hans situasjon og ta ansvar for den svake (9).

\section{Oppsummering}

Vi bruker funnene i studien til kvalitetsutvikling på posten vår. Avdelingen har utarbeidet to informasjonsbrosjyrer, en om PTA-fasen pasientene går igjennom og en brosjyre med informasjon om hvordan det tverrfaglige teamet jobber. Alle på avdelingen er informert om dette prosjektet og ble tatt med i utarbeidelsen av informasjonsbrosjyrene.

Vi har også holdt et framlegg på den internasjonale sykepleiedagen ved Oslo universitetssykehus, Ullevål. Dette er noe vi håper å få gjøre igjen. Siden det finnes lite forskning på dette området, ser vi dette som et viktig prosjekt. Vi kommer til å jobbe videre med å forbedre rutinene ved vår avdeling og foreta nye søk i databaser for å følge med om det publiseres videre forskning på området. IIII

\section{REFERANSER}

Finset A, Krogstad J M. Head injury- a public health problem. Oslo: Cappelens Forlag AS, 2002.

2. Andelic N, Sigurdardotteir S, Brunborg C, Røe C. Incidence of hospitaltreated traumatic brain injury in the Oslo population. Neuroepidemiology 2008; 30 : 20-128

3. Andelic N, Hammergren N, Bautz-Holter E, Sveen U, Brunborg C, Roe C. Functional outcome and health-related quality of life 10 years after moderateto-severe traumatic brain injury. Acta Neurol Scand 2009; 120: 16-23.

4. Jumisko E, Lexell J, Soderberg S. Living with moderate or severe traumatic brain injury. The meaning of Family Members Experiences. Journal of Family Nursing 2007; 13: 353-369.

5. Ponsford J, Oliver J, Ponsford M, Nelms R. Long-term adjustment of families following traumatic brain injury where comprehensive rehabilitation has been provided. Brain injury, 2003; 17: 453-468.

6. Hanoa R, Alvsåker K. Hjerneskaderehabilitering i tidlig fase. Tidskr nor legeforen 2008; 128: 66-67.

Dallan O. Metode akademisk, 2000.

8. Engrobs 200 . sykehus? Sykepleien 2003: 91(21): 35-37.

Kyrkevold M. Sykepleieteorier. 2 utgave. Oslo: Gyldendal Norsk Forlag, 2007.

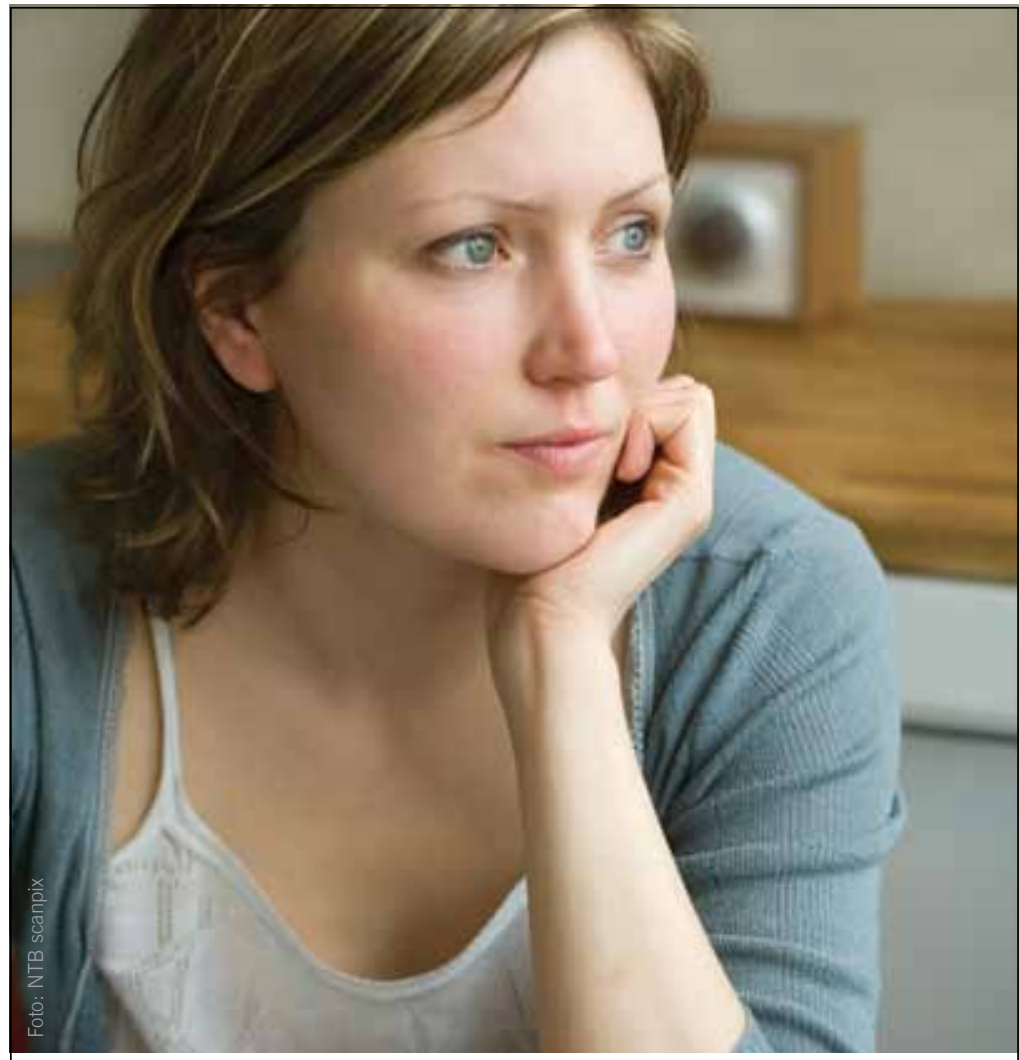

\section{Lurer du på noe om kreft?}

\section{Treffer du pasienter som har mye på hjertet?}

Kreftlinjen er åpen for alle - pasienter, pårørende, helsepersonell, arbeidsgivere og andre. Her kan du snakke med andre fagpersoner eller henvise andre som har spørsmål om kreft og kreftrelaterte emner som

- Hvordan man snakker med barn om kreft

- Nav, rettigheter og sykepenger

- Kreftkoordinator i kommunene

- Ny kreftbehandling

Kreftlinjen har mer enn 25 års erfaring og bred kompetanse innen kreftomsorg. Hos oss treffer du sykepleiere, sosionomer og jurister med taushetsplikt og tid til å lytte. Tjenesten er gratis fra fasttelefon og har vanlig takst fra mobil.

Åpningstider: mandag-torsdag: 0900-2000, fredag: 0900-1500 Vi snakker norsk og engelsk - og somali og polsk på tirsdager kl. 1500-2000.

\section{Ring 80057338 (800 KREFT) eller chat} med oss på kreftforeningen.no

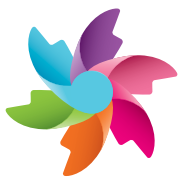

KREFTFORENINGEN 